Succession Management Practices in Australian Organizations

\author{
Associate Professor Tracy Taylor \\ Faculty of Business \\ University of Technology, Sydney \\ PO BOX 123 Broadway \\ NSW, Australia
}

Ph. (61) 295145112

T.Taylor@uts.edu.au

\author{
Peter McGraw \\ Senior Lecturer \\ Macquarie Graduate School of Management \\ Macquarie University
}

NSW 2109

Australia

(61) 298509034

Peter.McGraw@mq.edu.au 


\title{
Succession Management Practices in Australian Organizations
}

\begin{abstract}
In order to assess the current usage of succession management programs in Australian based organizations, and gain information on the characteristics and perceived effectiveness of such programs, a national research study was undertaken. A total of 711 human resource management professionals from a range of organizations across the country answered the questionnaire, a response rate of 59 percent. Succession management programs were present in less than half of the respondent's organizations. Furthermore, these programs were generally less than 5 years old. The prime imperatives for introducing succession management programs were reported as the desire to improve business results, and the need for new skill requirements in the business. A relationship between organization size, industry and type and the likelihood to use succession management was found. Common perceptions concerning the characteristics of effective succession management programs were also identified and are described in the paper. In brief, these are: high level involvement by the CEO; senior management support; line management involvement in identifying candidates; developmental assignments as part of the process; and succession management linked to business strategies.
\end{abstract}

Key words: succession management; succession planning; high potential employees 


\section{Introduction}

As businesses search for new and/or better means of achieving competitive advantage, the capacity of every functional area to improve organizational performance is under scrutiny. The strategic alignment of succession management programs to human resource management systems is an indicative response to these pressures. Succession management programs strive to develop and retain high potential employees, and thus provide the organization with a guaranteed managerial talent source and competitive human resource advantage. However, research to assess the extent and nature of succession management programs in relation to human resource management strategy and practice is somewhat limited, in both scope and geographical coverage. This research aims to empirically investigate the use of succession management programs in Australian organizations and explore policy and process dimensions. Of particular interest is the effect of succession management structures and processes on the perceived effectiveness of a succession management program. Furthermore, the research investigates the extent to which alignment of succession management with organisational strategy occurs.

In addition, the shifts of contemporary workplace demographics have highlighted that the retention and development of high potential talent is a crucial management issue for all businesses, especially in relation to dimensions of competitive advantage and the alignment of business and human resources strategy (Boxall \& Purcell, 2003; Schuler, Jackson \& Storey, 2001). As organizations strive to implement systems that address these current and predicted high levels of management attrition and turnover, succession management 
programs are receiving increasing attention (Baruch, 1999a; Byham, 2002; Gutteridge, Leibowitz \& Shore, 1993; Leavitt, 2001; Liebman, Bruer \& Maki, 1996; Sullivan, 2000).

Several reports have raised significant concerns in the business community about the increasing difficulty of retaining good staff at executive levels across all industry sectors (Dodd, 2001; Linkage, 1999; Rothwell, 2000). Also, substantial increases in senior personnel retirement levels, combined with high demand for qualified and effective management employees and accompanying staff turnover, have placed new demands on the retention and internal career development elements of HR systems. As the baby boomer generation starts to leave the workforce in significant numbers many businesses are facing the prospect of a sizeable proportion of senior management departures in the next three to five years (Bernthal, Rioux, \& Wellins, 1999; Guilford, 2000). Quantifying the situation, HR Magazine (Grossman, 1999) estimated that the number of 35 to 45 year olds in the United States is projected to decline by 15 percent between 2000 and 2015, thereby substantially reducing the talent pool from which new business leaders will emerge. In Australia, the labour force participation rate is projected to decline by 10.6 percent in the next 5 to 10 years, primarily due to high retirement levels (Australian Bureau of Statistics, 1999).

In response to some of the trends discussed above, many organizations have started to internally target and develop talented staff using criteria that are linked to future organizational needs and role capabilities (Huang, 2001). In other words, succession management approaches are being used to facilitate effective organizational positioning and development to ensure that within an organization the 'right' leaders are available at the 'right' time (Rothwell, 2000).In Australia to date however, the little research that has been done on succession management has reported limited strategic use of succession 
management. A 1990 study of HR managers who were members of the Institute of Personnel Management of Australia or the Australian Institute of Training and Development found that succession /replacement planning was the $9^{\text {th }}$ most used career development practice yet only 2.95 percent of respondents indicated their organization intended to continuously develop succession planning (Rylatt, 1993). The top three factors influencing career development were organizational commitment, to develop the organization's strategic plan, and to develop or promote from within. Interestingly, keeping up with competitors was low (2.2 \%) and improving business results was not even mentioned. This no doubt supports Rylatt's comment that prior to the 1990s little had been done by Australian businesses to link organization needs with those of the employees in the area of career development, succession planning was considered to be an aspect of career development.

A plethora of claims about the benefits of formal and strategic succession management programs are found in both professional journals and the dossiers of human resource management consulting firms. Many of the latter are involved in the development of organization specific succession management program design.

Broadly, the claimed benefits of succession management programs are that they facilitate effective workforce planning whereby the right people are in the right place at the right time to achieve successful business outcomes. At the heart of succession management is the identification and development of candidates with the skills, knowledge and capabilities to fill critical roles in the organization. The critical dimensions of succession management are further elaborated on in the following section, along with related literature on how best to effectively implement such programs. 
A limited Internet search using Google (with an English language restriction) yielded 98 different consulting firms promoting their succession management services (2 December 2002), this represented an increase of some 34 percent on the same search conducted six months earlier (5 June 2002). By 2004 the number had further increased to over 150 companies with succession management services and complementary software products (February, 2004). Despite this rapid growth in succession management consultancy service provision, there is a distinct lack of empirical evidence and academically rigorous research that supports the generic contentions of a positive relationship between formalised succession management practices and organizational performance (Huang, 2001).

To broaden the knowledge base about succession management beyond its virtually exclusive North American focus, a nationwide study was undertaken to gather data on factors that influence, characterise and underpin succession management practices in Australian organizations. The aim of the research was to develop a better understanding of succession management programs within the Australian context, and to make a contribution to the literature on succession management from a human resource management perspective. The three objectives of this study were to firstly, investigate how organizations make succession decisions, secondly, to determine which characteristics of succession management plans are perceived to impact on organizational effectiveness; and thirdly, assess the relationship between succession management approaches and organizational performance.

\section{Succession management programs}

Succession management has evolved from "succession planning”, which was a data-intensive method used to determine likely replacements of senior managers. An air of secrecy often accompanied the latter approach, promotion expectations were not always made clear and 
measurement could be perceived as highly ambiguous (Liebman, Bruer, \& Maki, 1996). Succession planning was not able to empirically demonstrate success in the retention of talented staff and effective replacement of departing senior management; this and its lack of face validity led many organizations to discontinue its implementation (Byham, Smith \& Paese, 2001).

Succession management was subsequently developed in an attempt to overcome the shortcomings of succession planning and to align with strategic business drivers. More specifically, the goal of succession management was to come up with a systematic process that could objectively and effectively respond to contemporary business imperatives such as organizational restructures, team based work systems, diversity issues, global outsourcing, and talent shortages (Baruch, 1999a; Metz, 1998). Kur and Bunning (2002: 761) argued that to successfully engage in succession management, 'the focus in organizations must shift from a narrow goal of developing individual leaders to that of developing the leadership function and the team of leaders who will lead the organization through significant change. This shift must impact everything from recruitment, to succession planning, compensation and executive development'. Therefore, conceptually succession management should incorporate a broad range of standardised performance evaluation methods and involves gathering information on employee performance from multiple perspectives; designed to supplement subjective manager judgements of potential with independent objective assessment data related to key succession criteria.

There is consensus in the literature that a well designed and operated succession management process can deal with dynamic work environments since it can be continually realigned to reflect current organizational business strategies and vision (Leibman, Bruer and Maki, 1996; Rioux \& Bernthal, 1999; Rothwell, 2000). This flexibility has been applied in 
cases of corporate downsizing, reengineering, decimated organizational levels, and broadened spans of managerial controls (Grossman, 1999). Research has also indicated that succession management efforts are most likely to be successful if they are embedded in management operations, involve HR and other managers throughout the organization and are concerned with implications for other career planning practices such as formal education training or secondments (Baruch, 1999a; Huang, 2001; Walker, 1998). Success is a function of meeting clearly stated succession management outcomes which encompass both organisational and individual level assessment.

Furthermore, succession management is an important characteristic of effective career management as noted by Baruch and Peiperl (2000) in their survey of 194 UK based companies. Succession management falls into the category termed by Baruch and Peiperl (2000:355) as ‘active planning' along with performance reviews, counselling by managers and counselling by HR. In their analysis, Baruch and Peiperl observed that these active planning processes 'were strongly associated with dynamic, open and proactive climates' (2000:357) and were particularly associated with organizations that relied heavily on internal labour markets. Conger (2002) argued that a positive career development culture in an organization assists with competitiveness, affirmative action and succession management, noting that 'a managed career development culture can pay great rewards to an organization and the people working in it’ (p 376)..

\section{$\underline{\text { Succession Management Components }}$}

Succession management programs range from those that elusively target executive level positions to programs that expansively encompass leadership development throughout all levels within an organization. At the 'top-end' the processes are aimed solely at CEO replacement, that is, the 'transference of ultimate executive authority from one to another' 
(Santora, Clemens, \& Sarros, 1997: 109). Broader based programs are, 'designed to ensure the continued effective performance of an organization, division, department or work group by making provision for the development and replacement of key people over time' (Rothwell, 1994:5). Most programs fall somewhere in-between, with coverage of senior and key strategic level positions the most common starting point for the organization (Rioux \& Bernthal, 1999).

Succession management programs focus on developmental processes, creating a clear picture of existing human resource strengths, relating these to anticipated needs and isolating areas requiring action (Elliott, 1998). One of the key components of succession management is the assessment of both the organization and its employees. A survey of employee attitudes toward career development and perceptions of succession management at the Nevada Operations Office of the Department of Energy showed many employees believed that succession management could provide them with effective opportunities for career and leadership development and that the employees perceived a need for leadership assessments for promotions (Kim, 2003). However, this acceptance was contingent upon a strong link between succession management and leadership/career development via clearly defined guidelines and models for leadership assessment and training in leadership competencies. Kim (2003) concluded that succession management practices should emphasize employee self-improvement by promoting cross-functional and cross-sector job assignments, executive coaching and mentoring.

While the components of an organization's succession management program can vary as much as its scope of application, there are several critical elements that have been 
identified as fundamental to effective succession management. Eastman (1995) offered the following list of commonly reported effective practices:

- receives visible support from the CEO and Top Management

- is owned by line management and supported by staff

- is simple and tailored to unique organizational needs

- is flexible and linked with the strategic business plan

- evolves from a thorough human resources review process

- is based upon well-developed competencies and objective of candidates

- incorporates employee input

- is part of the broader management development effort

- includes plans for development job assignments

- is integrated with other human resource systems

- emphasises accountability and follow-up.

These items are supported by other studies that have found highly effective succession management systems are characterised by CEO involvement, support of senior management, line management identification of candidates, use of developmental assignments, and succession management processes linked to business strategies (Purcell, 1995; Rioux \& Bernthal, 1999; Tyson, 1997). More recently, Conger and Fulmer (2003) came up with five 'rules' for succession management. Rule one, the fundamental rule on which the other four are build, is a focus on development, succession management must be a flexible system oriented toward developmental activities. Rule two is focus on linchpin positions, jobs that are essential to the long-term health of the organization. Rule three is make succession management transparent, no secrecy. Rule four is regular measurement of progress, moving away from the replacement mind-set of succession planning. Rule five is keep it flexible. 
Conger and Fulmer (2003:) stated that 'succession management systems are effective only when they respond to users' needs and when the tools and processes are easy to use and provide reliable and current information.. at the foundation of a shift toward succession management is a belief that leadership talent directly affects organizational performance.'

Given the research literature on the benefits of succession management programs it is reasonable to assume that organizations with programs in place would report better results on employee retention and career development options. It is also plausible to suggest that organizations using succession management programs that incorporate previously identified ‘effective practices’ (Eastman, 1995) would report higher satisfaction with their programs than organizations that were not using these same practices.

Taking these findings as a starting point, the current research aimed to empirically investigate succession management and associated HR outcomes by assessing the extent to which succession management is used as part of human resource management strategy in Australian organizations, the reasons for its deployment, the structures and processes employed, and its perceived effectiveness.

\section{Method}

The Australian Human Resources Institute (AHRI) and Development Dimensions International (DDI) partnered the study with the former providing the sample database and the latter contributing the survey instrument. The questionnaire was initially developed to assess succession management policies, practices and outcomes (Rioux \& Bernthal,1999). As the survey instrument had been developed and implemented in North America, some terms needed to be tested for Australian workplace conditions, culture and terminology. An adapted 
questionnaire was pre-tested with five human resource management consultants and minor adjustments were made to wording. The revised questionnaire was then piloted with 10 human resource managers selected to represent a cross-section of industry sectors, private, public, small, middle and large, national and multinational organizations. The pilot respondents recommended no further changes and the final version of the questionnaire was forwarded to AHRI for distribution.

An introductory email was sent out by AHRI to a stratified sample of 1,200 members setting out the study aims and inviting participation in the study. The sample was selected by choosing members who worked for the top 1500 organizations in Australia, as defined by AHRI. As some organizations had multiple members, the member with the most senior HR position was included in the study. A link to the website which hosted the questionnaire was provided allowing respondents to complete the form and submit their answers electronically. There was provision for a hard copy of the questionnaire to be posted out and five requests were received for this option. All responses were anonymous and the electronic data collected and processed by a neutral third party, Optimax Consulting.

By the end of the first week of the survey, 412 respondents had electronically completed the questionnaire. At this point a reminder email was sent to the whole distribution list and at the close of the survey period 711 valid responses had been received, a response rate of 59 percent. Some 72 percent of respondents requested a summary of the study findings by suppling an email contact, this address was kept separate from their questionnaire responses for reasons of confidentiality.

The response rate of 59 percent is well within the average response rate reported by Baruch (1999b) [55.6 with a standard deviation of 19.7] in his study of academic studies' 
response rates in the behavioural sciences. It is, however, somewhat higher than his suggested norm for responses from representatives of organizations $(36+/-13)$. Follow up reminders and incentives can increase response rates and both were employed in this study to good effect. Other contributing factors to the relatively high response may be related to the distribution of the survey by the national professional HR association and the fact that it was one of the first internet based surveys of its members.

The initial group of questions were focussed on the use of succession management in the organization. If the respondent organization did not have any such programs in place they were instructed to click a hot-link that would take them to the descriptive organization questions at the end of the questionnaire. If the respondent organization did have a succession management program in operation they were instructed to continue with their responses.

As it was proposed that the system characteristics of an organization's succession management program would have a relationship with the types of benefits and level of perceived effectiveness of the program, questions about succession management program characteristics were asked using two separate 16 item, seven-point scales with descriptive anchors. The first examined system characteristic items such as the extent to which the program was linked to business strategy planning, the level of involvement of the CEO and other senior staff in the selection and nomination process, how candidates were identified, and the extent to which various developmental processes were used. The second addressed the perceived benefits of instigating a succession management program into the organization. The indicators used focused on the organization's systems relating to promotion and careers, compensation and rewards, performance management, and training and development (a copy of the questionnaire is available from the author on rquest). 
Results

Of the respondents constituting the effective sample, 66 percent were Human Resource Managers or Directors and 34 percent some other HR role. Some 68 percent of the respondents worked for national organizations. Of the 32 percent working in multinational organizations, Australian (38\%) and American owned (15\%) were the largest groupings. Services based organizations (28\%); finance/insurance (10\%); education (10\%), and manufacturing (8\%) were the main sectors represented. Company size ranged from under 50 employees (19\%) to over 500 employees (51\%). Summary statistics indicate that the organizations included in the study were reasonably representative of the top 1500 Australian organizations.

The first step in this study was to simply gauge the presence or absence of succession management programs relative to industry type or size and perceived organization performance. The second step was to explore the succession management system construct and its dimensionality.

In terms of the overall profile, some 44 percent of respondents replied that their organization had a formal succession management program, which, on average, covered 55 percent of employees within the organization. The size of the organization was a significant predictor of likelihood of having a succession management plan in place. It should be noted here Australia has a very large number of small businesses and that this was reflected in the responses, with 18 percent coming from organizational units with less than 50 employees. However, we are not claiming that the data are representative of all businesses in Australia. As would be expected given that the survey was distributed by the professional HR body 
direct to its members, respondents are typically those who work in firms with formal HR practices. As such the population is highly representative of firms in Australia with formal HRM. ${ }^{i}$ Table 1 provides a summary of the survey results by organization size.

Take in table 1

Manufacturing, transportation, communication and retail/wholesale sector organizations were significantly more likely to report having formal succession management programs, and education and service-based industries were least likely to have formal plans. Multinationals reported a higher incidence of formal succession management programs (63\%) compared with national-only companies (42\%). Of those with formal plans, 75 percent had been using them for five or fewer years (median 4 years, mode 2 years). In describing the organization's approach to succession management, the majority of respondents (61.3\%) indicated that their organization took a 'pool' approach, which was defined as, 'worked to develop a reservoir of qualified candidates who were capable of filling vacancies' on the questionnaire. This was followed by the 'react' approach (26.5\%), 'wait until a position opens then start searching for a replacement', and then there was the 'heir' approach (12.3\%) of 'identifying and nurturing a single heir for each position'. In analysing approaches taken by organisations according to industry sector, as detailed in Table II, differences between sectors were apparent. The heir approach was most common in retail/wholesale and manufacturing; the pool was most largely used in finance insurance real estate, transport communication and utilities, and education; and construction/mining and services were the main implementers of a react approach.

\section{Take in Table II}


The reason for using a succession management program is presented in Table III. The data indicate that the overwhelming reasons for the use of succession management programs are related to improving business results and responding to new business opportunities. A third reason offered was the use of succession management to increase employee diversity.

Take in table III

When making succession decisions, 89 percent of respondents replied that the employees’ career wishes and aspirations were considered, a characteristic found in all three levels of implementation. However, respondents who reported that succession management process information, such as nominations, performance, and standings was not shared with the candidates involved in the succession management process were much more prevalent in the low and mid-level implementer group. Those reporting use of heir and pool approaches in their programs appeared in both the high and mid-level categories of succession management implementers, whereas the organizations adopting a react approach were exclusively found in the low-level category.

When evaluating candidates for succession, two primary sources of data were used by nearly all organizations. These were recommendations (96\%) and performance management data (93\%). The use of a wide range of techniques is indicative of a well-developed and wellresourced succession management program as demonstrated by the finding that the high-level implementers used significantly more evaluation methods $(M=5.3)$ than the mid-level $(M=3.4)$ or low-level group ( $M=2.0)$. Respondents who reported having highly effective succession management systems were_significantly more likely to evaluate succession 
candidates using a range of methods, particularly multirater instruments (i.e., 360-degree feedback) and simulations (including assessment centres). It is probable that the actual technique used is not the issue here but rather having a comprehensive approach within the evaluation program provides a strong indicator of the program's perceived effectiveness.

The extent to which an organization’s succession management process was linked to other human resource management system is represented in the Table IV data. Most organizations related succession management systems to their performance management, career planning, training, and generic management development programs. However, few respondent organizations linked succession management systems to compensation, EEO, or affirmative action.

Take in Table IV

In accord with other studies that have looked for groupings of HR/career practices, such as Baruch and Peiperl (2000), we conducted a factor analysis to gain a better understanding of the structure of the data on the 16 variables used to assess succession management qualities/characteristics. Each respondent was asked to indicate the degree to which these characteristics were present in their organizations' current approach to succession management using a three-point scale (1= very much, $3=$ not at all). Two interpretable factors emerged and we termed these succession management application levels and summed the items forming each factor to create a scale of that variable. The first factor, contained 'strategic' succession management practices (alpha $=.85$ ) contained thirteen items (development opportunities included as part of succession management, used to improve organizational outcomes, is linked to strategy, visibly supported by senior management, used 
for future job openings, involves the CEO, considers career wishes, collects assessment data, openly shares assessments, has well-defined requirements, shares ownership across all levels, mentoring and employee development is rewarded, time frames are set for action), The second factor, 'reactive’ practices (alpha $=.53$ ) contained four items (used to fill existing jobs, uses line managers to identify candidates, relies on HR staff to run, tracked on a computerised system). Table V outlines these results.

Take in Table V

We tested for a principal component grouping amongst the types of succession management practices employed by organizations but found none. Subsequently, we determined the scope/level of an organization's succession management program by the number of succession management practices engaged in by the organization. This is consistent with other studies that identified the number of practices used corresponded with the level of sophistication and effectiveness of the program (Eastman, 1995). Three distinct categories were apparent; organizations that fully employed less than four practices and therefore were termed low-level succession management implementers; mid-level implementers employed 4-6 practices; and high level were those fully employing more than six practices in their programs. The first group comprised 89 low-level succession management organizations, the second 142 mid-level and the third, 73 high-level effective practice organizations. The final step was to examine the relationship between these three levels of succession management implementation and their perceived performance and benefits relative to wider organizational outcomes.

In rating the overall effectiveness of the current succession management approach (on a scale of 1=not at all, 5 moderately, 10= extremely) high-level implementer organizations 
rated their overall succession management decision making as highly effective $(M=8.5)$, mid-level implementers $(M=6.0)$ and low-level implementers $(M=5.2)$. Respondents that reported their organization was achieving above average customer satisfaction, employee satisfaction and retention of quality employees, rated their succession management system moderately to highly effective. By way of illustration, 80 percent of organizations with ‘highly effective’ rated succession management programs reported above average employee satisfaction but only 11 percent with 'less than effective' rated succession management reported above average employee satisfaction. Additionally, organizations that had 50 percent or more employees in a succession management program noted an improved retention of quality employees and employee satisfaction.

All respondents, regardless of whether the organization they were working in had a succession management program or not, were provided with an open-ended question to describe their experience of succession management programs and outline practices they felt were particularly effective. The most frequently cited criteria for effectiveness (73\%) was having organizational support and senior management involvement in the process of identifying competencies/key requirements. Other aspects which were identified as effective were involving line management in the process design, implementation, and execution (43\%), and alignment with company strategy, competencies, and values (38\%). Several respondents (32) noted that the most effective methods for identifying candidates were those based on a range of techniques not just recommendations. Respondent comments also highlighted the importance of exposing employees to multiple situations, tasks and projects to build their competencies, and using coaching and mentoring by senior staff. 


\section{Discussion}

The survey results suggest that organizations benefit most when multiple techniques are used in concert and succession management integrates with other HR systems and strategically links to the overall business plan. This integration allows the system to respond to changing organizational needs and to contribute to the bottom line. Although only 44 percent of organizations reported succession management programs, an additional 28 percent indicated that they were likely to introduce a succession management system in the next 1-2 years. The main reasons for this intended introduction were the desire to improve business results (69\%) and changes in business demands that will create new skill requirements (47\%). These results support the notion that succession management is a relatively new but growing part of businesses efforts to develop internal talent, meet organizational needs, improve business results and become more strategically responsive.

There are two overarching conclusions that may be derived from this study. First, size and multinationality are major indicators of the likelihood of an organization engaging in succession management programs. Not surprisingly, the largest organizations are those most likely to have programs in place, however size did not affect the type of program with large organizations equally distributed across the low, mid, and high-level implementers. Second, there is a relatively robust relationship between the succession management system characteristics and its perceived effectiveness.

This study empirically identifies different succession management system characteristics and demonstrates their relationship to organizational and HR performance. From the perspective of respondents the most effective approaches to succession management involve all levels of the organization in the planning and development of the 
system, and strategic positioning of the system to better equip the organization to meet the changing demands of the business environment they are operating within.

The responses indicate that most organizations rely on performance management data and recommendations to identify candidates. Performance management provides data on candidates' past performance and is used to identify developmental needs. Recommendations based on past performance were viewed as useful, but not always reliable, data and were often employed as just part of the assessment process. However, the use of validated and standardised evaluation methods was a distinguishing factor between effective and ineffective succession management plans. This finding is consistent with the American Productivity and Quality Centre (Leavitt, 2001) report on best practice organizations in the United States that found that such organizations use a core set of succession management competencies to identify candidates. The same report also revealed that best practice organizations engage future leaders by implementing individualised developments plans. This finding was replicated in the current study with respondents indicating that tailoring programs to meet candidates career goals and aspirations produced a better person-job fit and led to greater satisfaction overall with the succession management process.

Comparing this study with the findings of research conducted in other countries reveals some interesting contrasts. A recent UK study of 279 organizations in the FT 500 reported that 90 percent of respondents used succession management for retention purposes (HRMSoftware, 2000). This reveals a slightly different focus for succession management than that reported by the Australian respondents in this study. In a survey of succession management in Taiwanese firms, Huang (2001) sampled 166 firms of which 65 percent reported having succession plans. Huang's overall conclusion was that the Taiwanese rate 
was much lower than the 93 percent noted in a 1995 Conference Board study. This study revealed only a 44 percent take-up rate amongst Australian respondent organizations but there were strong indications that several of the surveyed organizations would be launching into succession management in the next 1-2 years. In making these observations it should be noted that it is problematic to make cross-cultural comparisons due to the limitation of the samples used in each case. At best, the data indicate a trend towards growth in the use of succession management processes, with some countries, such as the United States, more likely to have broadly implemented such systems than others, such as Australia.

The HRMSoftware study (2000) reported the key driver in succession planning was retention (90\%), followed by the need to align business and HR strategies (70\%). The Australian respondents in this study rated the desire to improve business results (69\%) as the number one reason for succession management planning, followed by the need for new skill requirements (47\%). Thus, in both studies strategy alignment was perceived as an important element of succession management. That retention was not a significant issue amongst the Australian respondents might be linked to different employment conditions or other country specific workforce situations.

Huang's (2001) study concluded that there was no empirical evidence to support the argument that Taiwanese firms that have succession management systems have better HR outcomes than those who do not. However, he found that the degree of system sophistication is systemically related to HR effectiveness (Huang, 2001: 743). The data collected for this study also suggests that the mere implementation of a succession management plan does not make a significant difference to reported business outcomes. Those organizations that rated the succession management process within their organization as highly effective were 
significantly more likely to report improved business results as an outcome effect than those organizations with less than effective succession management programs. While the perceived effectiveness of an organization's succession management program and HR performance were strongly correlated this does not mean that the better succession management programs produce better HR outcomes. The way in which a succession management program is developed and implemented is likely to be reflective of how the organization approaches its HR function in general. As such, a highly effective succession management process would be representative of a highly effective HR system with each feeding into the other. To isolate one dimension only would be highly problematic without controlling for the full range of HR practices.

\section{Conclusion}

Given the responses of human resource management professionals within this and other studies, it is evident that succession management requires substantial ongoing organizational commitment across all levels of the business for effective implementation. A key component for effectiveness was identified as having support for the process not only at the highest levels but also all the way down the line. In particular, senior management must be prepared to provide support and development opportunities for staff identified as high potential. Nearly 80 percent of respondents indicated that they believed strategic and effective succession management is becoming a critical factor of business success. For many organizations succession management is still in its infancy, as evidenced by the large number of programs that have only recently been established. Similar to the UK study (HRMSoftware, 2000) most respondents stated that they were intending to extend the scope of their succession management plans. 
A limitation of this study was the examination of only the system and practices involved in the implementation of succession management programs. The research did not attempt to identify organizational culture or sub-surface influences on decision-making about selection of these practices or their implementation. Previous research has identified that succession decisions can be affected by organizational performance with sociopolitical processes moderating the relationship (Boeker \& Goodstein, 1991; Puffer \& Weintrop, 1991), and unsystematic risk influencing succession decisions (Cannella \& Lubatkin, 1993). Conger and Fulmer (2003) also suggested that good succession management is possible only in an organizational culture that encourages candor and risk taking at the executive level, and where the truth is valued. Kur and Bunning (2002) further stressed the importance of a supportive organizational culture if succession management is to work. Therefore, future research could build on the findings presented here by qualitatively investigating sociopolitical aspects of decision-making impacts within formal succession management processes.

Furthermore, a longitudinal measurement of effectiveness of a succession management system is a logical extension from this study and other previous research. Reported studies to date have not assessed the impact of succession management plans from the pre-program through to full-scale and long-term implementation. Longitudinal research could measure change to the specific dimensions that the implementation of a succession management program is purported to positively impact upon. This could include responsiveness to organizational restructures, fostering of team development, and increasing levels of workplace diversity. The measurement of outcomes and performance over time is especially relevant to the Australian situation as revealed in this study given the relative infancy of succession management program implementation. 
Before closing, some possible limitations of this study should be noted. A potential source of bias may relate to the characteristics of non-respondents to the survey. It is plausible to speculate that non-respondents might be less likely to have sophisticated or effective succession management systems and that these influenced their non response. A further suggestion for future research would be the use of multiple informants within an organization. This would provide a more comprehensive dataset allowing for representation of not only HR managers and staff involved in the implementation of the succession management program but also provide information from the perspective of the participants. Future research might try to refine the constructs of succession management program systems and the differentiation between the levels of implementation could be also be further clarified. Accordingly, such research could be undertaken using a cross-section of countries to provide a richer global information base from which human resource managers and researchers would benefit.

\section{References}

Australian Bureau of Statistics. (1999). Labour force projections, Australia, 1999-2016, No. 6260.0. Canberra: Australian Government Printing Service.

Baruch, Y. (1999a). Integrated career systems for the 2000s. International Journal of Manpower, 20 (7): 432-457.

Baruch, Y (1999b). Response rate in academic studies — A comparative analysis. Human Relations, 52 (4) 421-438.

Baruch, Y. \& Peiperl, M. (2000). Career management practices: An empirical survey and implications. Human Resource Management, 39 (4) 347-366. 
Bernthal, P., Rioux, S., \& Wellins, R. (1999). The leadership forecast: A

benchmarking study. Pittsburgh: Development Dimensions International.

Boeker, W., \& Goodstein, J. (1991). Organizational performance and adaptation: Effects of environment and performance on changes in board composition. Academy of Management Journal, 34: 805-826.

Boeker, W., \& Goldstein, J. (1993). Performance and successor choice: the moderating effects of governance and ownership. Academy of Management Journal, 36(1): 172-86.

Boxall, P \& Purcell, J (2003). Strategy and Human Resource Management, Basingstoke: Palgrave Macmillan.

Byham. W.C. (2002) Headstart: A new look at succession management. Ivey Business Journal, May/June. Toronto, Ontario: Ivey Management Services.

Byham, W. C., Nelson, G. \& Paese, M. (2000). Cultivating leaders with an acceleration pool. Health Forum Journal, http://www.healthforum.com .

Byham, W., Smith, G., \& Paese, M. (2001). Grow your own leaders. Pittsburgh: Development Dimensions International. 
Caudron, S. (1996). Plan today for an unexpected tomorrow. Personnel Journal, 75 (9): 4045.

Cannella. Jr. A.; \& Lubatkin, M. (1993). Succession as a sociopolitical process: Internal impediments to outsider selection. Academy of Management Journal, 36 (4):763-794.

Conger, S. (2002). Fostering a career development culture: Reflections on the roles of managers, employees and supervisors. Career Development International. 7 (6/7) 371-376.

Conger, J., \& Fulmer, R. (2003). Developing Your Leadership Pipeline. Harvard Business Review, 81, (12) 76-85.

Dodd, K. (2001). Knowing how to keep your best and brightest. Workforce, 12: 57-60.

Eastman, L. (1995). Succession planning: An annotated bibliography and summary of commonly reported organizational practices. Greensboro, North Carolina: Centre for Creative Leadership.

Elliott, S. (1998). (Ed). Recruiting for success: Hiring and keeping the right management talent. Houston: APQC.

Grossman, R. (1999). Heirs Unapparent, HR Magazine, February: 36-44. 
Guilford, R. (2000). Succession planning getting little real attention.

BizJournals.com/Atlanta, accessed on August 282002.

Guinn, S.L. (1997). Change before you have to: For CEOs who recognize the need, the tools exist now for organizational change. Career Development International, 2 (5): 225-228.

Gutteridge, T., Liebowitz, Z. \& J. Shore (1993). (Eds) Organizational Career Development. San Franciso: Jossey-Bass.

Finkelstein, S., \& Hambrick, D. (1996). Strategic leadership: Top executives and their effects on organization. St Paul: West.

Hagberg Consulting Group (1999). Succession planning process. www.hcgnet.com, accessed on 1 August 2002..

Hambrick, D.,Geletkanycz, M., \& Frederickson, J. (1993). Top executive commitment to the status quo: Some results of its determinants. Strategic Management Journal, 14 (6): 401-18.

HRM Software (2000). Survey of succession planning practices in major UK organization. London: HRMsoftware.

Huang, T. (2001). Succession management systems and human resource management outcomes. International Journal of Manpower, 22 (8) 736-747. 
Kim, S. (2003). Linking employee assessments to succession planning. Public Personnel Management. 32 (4) 533-548.

Kur, E., \& Bunning, R. (2002).Assuring corporate leadership for the future. The Journal of Management Development. 21 (9/10) 761- 780.

Leavitt, P. (2001). (Ed.) Succession management: Identifying and cultivating tomorrow’s leaders. Houston: American Productivity and Quality Center.

Liebman, M., Bruer, R., \& Maki, B. (1996). Succession management: The next generation of succession planning. Human Resource Planning, 19 (3): 16-29.

Linkage Inc. (1999). Best practices for identifying, developing and retaining emerging leaders, Executive summary of a Bennis/Linkage research study, http://www.linkageinc.com accessed on 25 July 2002.

Linkage Inc. and J. Howard \& Associates. (1999). Leading diversity: Benchmarking successful practices for the global marketplace, http://www.linkageinc.com accessed on 25 July 2002.

Linkage Inc., \& the University of Michigan Business School. (2000). Action learning, leveraging learning to achieve organizational change \& development, http://www.linkageinc.com accessed on 10 July 2002. 
Metz, E. (1998). Designing succession system for new competitive realities. $\underline{\text { Human }}$ Resource Planning, 21 (3): 31-37.

National Academy of Public Administration. (1997). Managing succession and developing leadership: Growing the next generation of public service leaders. Washington: NAPA HRM Series III.

Puffer, S. M., \& Weintrop, J. B. (1991). Corporate performance and CEO turnover: The role of performance expectations. Administrative Science Quarterly, 36: 1-19.

Purcell, D. (1995). Corporate strategy and human resource management. In Storey, J., Human Resource management - A critical text (pp. 63-86). London: Routledge.

Rioux, S., \& Bernthal, P. (1999). Succession management practices survey report. Pittsburgh: HR Benchmark Group.

Rothwell, W. (1994). Effective succession planning: Ensuring leadership continuity and building talent from within. New York: Amacom.

Rothwell, W. (2000). (2 ${ }^{\text {nd }}$ Ed) Effective succession planning: Ensuring leadership continuity and building talent from within. New York: Amacom. 
Rylatt, A. (1993). Career Development in Australia: Recognizing the need for linkage with business strategy. In T. Gutteridge, Z. Liebowitz, \& J. Shore (Eds) Organizational Career Development. San Franciso: Jossey-Bass, p57-.

Santora, J., Clemens, R., \& Sarros, J. (1997). Views from the top: Foundation CEOs look at leadership succession. Leadership \& Organization Development Journal, 18 (2): 108-115.

Schall, E. (1997) .Public Sector Succession: a strategic approach to sustaining innovation. Public Administration Review, 57 (1): 3.

Schuler, R., Jackson, S.E. \& Storey, J. (2001). HRM and its link with strategic management, in J. Storey (Ed) $\underline{\text { Human Resource Management: A Critical Text }} 2^{\text {nd }}$ Ed, London, Thompson Learning.

Sullivan, J. (2000). Recruiting and retaining key talent. Lexington, Mass.: The Center for Organizational Research.

Tyson, S. (1997). Human resource management comes of age: strategic integration. in S. Tyson, Human resource strategy (pp. 1-15). London: Pittman.

Walker, J. (1998). Do we need succession planning anymore? Human Resource Planning, 21 (13): 9-12. 
Wallum, P. (1993). A broader view of succession planning. Personnel Management, 25 (9): 42. 
Table 1: Formal succession management by size of organization

\begin{tabular}{|l|r|r|r|r|r|r|}
\hline $\begin{array}{l}\text { Do you have a } \\
\text { succession } \\
\text { management } \\
\text { plan }\end{array}$ & $\begin{array}{l}\text { Under 50 } \\
\text { employees }\end{array}$ & $\mathbf{5 0 - 9 9}$ & $\mathbf{1 0 0 - 1 9 9}$ & $\mathbf{2 0 0 - 4 9 9}$ & Over 500 & $\begin{array}{l}\text { Total number of } \\
\text { respondents }\end{array}$ \\
\hline YES & $33(4.6 \%)$ & $23(3.2 \%)$ & $23(3.2 \%)$ & $52(7.3 \%)$ & $180(25.3 \%)$ & $311(43.7 \%)$ \\
\hline NO & $98(13.7 \%)$ & $32(4.5 \%)$ & $36(5.0 \%)$ & $71(10.0 \%)$ & $163(22.9 \%)$ & $400(56.1 \%)$ \\
\hline TOTAL & $129(18.4 \%)$ & $55(7.7 \%)$ & $59(8.2 \%)$ & $123(17.3 \%)$ & $343(56.2 \%)$ & $711(100 \%)$ \\
\hline
\end{tabular}

Table II - Type of system used by core business

\begin{tabular}{|c|c|c|c|c|c|c|c|c|c|}
\hline $\begin{array}{l}\text { Core } \\
\text { business }\end{array}$ & Manufacturing & $\begin{array}{l}\text { Finance } \\
\text { insurance } \\
\text { real estate }\end{array}$ & Services & $\begin{array}{l}\text { Transport } \\
\text { comm } \\
\text { utilities }\end{array}$ & $\begin{array}{l}\text { Retail } \\
\text { wholesale }\end{array}$ & Education & $\begin{array}{l}\text { Construction } \\
\text { mining }\end{array}$ & Other & Total \\
\hline Heir & $21.1 \%$ & $10.3 \%$ & $13.3 \%$ & $6.7 \%$ & $28.6 \%$ & $6.7 \%$ & $8.3 \%$ & $7.5 \%$ & $12.3 \%$ \\
\hline Pool & $57.9 \%$ & $74.4 \%$ & $49.3 \%$ & 73.3\% & $61.9 \%$ & 73.3\% & $50.0 \%$ & $62.5 \%$ & $61.3 \%$ \\
\hline React & $21.1 \%$ & $15.4 \%$ & $37.3 \%$ & $20.0 \%$ & $9.5 \%$ & $20.0 \%$ & $41.7 \%$ & $30.0 \%$ & $26.5 \%$ \\
\hline Total & $100.0 \%$ & $100.0 \%$ & $100.0 \%$ & $100.0 \%$ & $100.0 \%$ & $100.0 \%$ & $100.0 \%$ & $100.0 \%$ & $00.0 \%$ \\
\hline
\end{tabular}

Table III: Implementer category by reason for succession management program

\begin{tabular}{|l|l|l|l|}
\hline $\begin{array}{l}\text { Reason for using succession } \\
\text { management }\end{array}$ & $\begin{array}{l}\text { \% of High- } \\
\text { level } \\
\text { implementers }\end{array}$ & $\begin{array}{l}\text { \% of Mid- } \\
\text { level } \\
\text { implementers }\end{array}$ & $\begin{array}{l}\text { \% of Low- } \\
\text { level } \\
\text { implementers }\end{array}$ \\
\hline Desire to improve business results & 70 & 90 & 60 \\
\hline $\begin{array}{l}\text { Demands in business created new } \\
\text { requirements }\end{array}$ & 18 & 20 & 16 \\
\hline Need for greater diversity in management & 15 & 12 & 10 \\
\hline $\begin{array}{l}\text { Anticipated changes in skills of future } \\
\text { leaders }\end{array}$ & 10 & 05 & 0 \\
\hline Company growth & 08 & 06 & 08 \\
\hline New CEO & 08 & 06 & 05 \\
\hline Immediate vacancies & 04 & 04 & 07 \\
\hline Retirement of current managers & 04 & 04 & 06 \\
\hline Recent merger/acquisition & 04 & 04 & 0 \\
\hline Poor promotion history & 02 & 04 & 02 \\
\hline Change in the management structure & 02 & 08 & 15 \\
\hline Need to increase retention & 0 & 0 & 0 \\
\hline
\end{tabular}


Table IV: System linkage to succession management by organizational category

\begin{tabular}{|l|l|l|l|}
\hline System & $\begin{array}{l}\text { \% of High-level } \\
\text { implementers } \\
\text { with link to SM }\end{array}$ & $\begin{array}{l}\text { \% of Mid-level } \\
\text { implementers } \\
\text { with link to SM }\end{array}$ & $\begin{array}{l}\text { \% of Low-level } \\
\text { implementers } \\
\text { with link to SM }\end{array}$ \\
\hline Performance management & 84 & 75 & 62 \\
\hline Training \& development & 78 & 72 & 52 \\
\hline Career planning & 76 & 60 & 51 \\
\hline Recruitment \& selection & 68 & 58 & 51 \\
\hline $\begin{array}{l}\text { Management development } \\
\text { programs }\end{array}$ & 61 & 53 & 42 \\
\hline Compensation & 47 & 33 & 24 \\
\hline EEO \& affirmation action & 24 & 20 & 14 \\
\hline
\end{tabular}

Table V: Factor Analysis Results

$\begin{array}{lll}\text { Approach to Succession Management } & \text { Strategic } & \text { Reactive } \\ \text { Is linked to strategy } & \mathbf{. 8 2} & .16 \\ \text { Used to improve organization outcomes } & \mathbf{. 7 9} & .18 \\ \text { Is supported by senior mgt } & \mathbf{. 7 6} & .27 \\ \text { Changes in response to changing business plan } & \mathbf{. 7 6} & .25 \\ \text { Development is included } & \mathbf{. 7 2} & .30 \\ \text { To fill future jobs } & \mathbf{. 7 1} & .26 \\ \text { Involves ceo } & \mathbf{. 7 1} & .23 \\ \text { Contains a time frame } & \mathbf{. 6 9} & .32 \\ \text { Open sharing process } & \mathbf{. 6 7} & .35 \\ \text { Uses objective assessment } & \mathbf{. 6 5} & .43 \\ \text { Shares ownership across all levels of organization } \mathbf{. 6 3} & .49 \\ \text { Managers are rewarded for development of staff } & \mathbf{. 6 1} & .47 \\ \text { Considers employees career wishes } & \mathbf{. 5 9} & .48 \\ \text { Lists well defined requirements } & \mathbf{. 5 7} & .43 \\ \text { Used to fill existing jobs } & .49 & \mathbf{. 7 2} \\ \text { Relies on hr staff } & .27 & \mathbf{. 6 7} \\ \text { Involves line managers } & .36 & \mathbf{. 6 7} \\ \text { Relies on a computerized tracking system } & .49 & \mathbf{. 5 2}\end{array}$

$\begin{array}{lll} & \text { Eigenvalue } & \text { CUM\% } \\ \text { Factor 1: Strategic } & 9.7 & 54.1 \\ \text { Factor 2: Reactive } & 1.0 & 59.9\end{array}$

\footnotetext{
${ }^{\mathrm{i}}$ Small businesses, (defined as those with 20 or less employee by the Australian Bureau of Statistics), employ almost 3.6 million people ,or 49\% of all private sector employees. (1321.0 Small Business in Australia, 2002, Canberra: ABS p1,whilst businesses with less than 50 employees comprise $97.5 \%$ of all business enterprises. ( $\underline{A}$ portrait of Australian business, 1998, Canberra: Department of Industry, Science and Tourism).
} 
